\title{
PENGARUH PEMBERIAN MINUMAN ADVOKAD FERMENTASI TERHADAP PERTAMBAHAN BERAT BADAN, TOTAL KOLESTEROL DAN KADAR UREASE DALAM DARAH TIKUS PUTIH JENIS WISTAR. ${ }^{1)}$.
}

\author{
Afriza Yelnetty*), Rahmawaty Hadju*), Maureen Tamasoleng*) dan Indyah \\ Wahyuni*) \\ Fakultas Peternakan Universitas Sam Ratulangi Manado, 95115. \\ email: afrizayelnetty@yahoo.co.id
}

\begin{abstract}
ABSTRAK
Penelitian ini bertujuan untuk mempelajari efek dari pemberian minuman adpokat fermentasi terhadap pertambahan berat badan, kolesterol dan kadar urea darah pada tikus. Minuman adpokat fermentasi terbuat dari buah advokad, skim milk, sukrosa, serta tiga jenis kultur starter campuran dari bakterri asam laktat yaitu; Streptococcus thermophillus, Lactobacillus acidophilus dan Lactobacillus rhamnosus. Penelitian ini menggunakan Rancangan Acak Lengkap yang terdiri dari 5 perlakuan dengan 7 ulangan, dimana R0; tanpa penambahan adpokad, R1; penambahan adpokat 2,5 $\mathrm{ml}, \quad \mathrm{R} 2$; penambahan adpokat $5 \mathrm{ml}, \quad \mathrm{R} 3$; penambahan adpokat $7,5 \mathrm{ml}$, dan $\mathrm{R} 4$; penambahan advokad $10 \mathrm{ml}$. Hasil penelitian menujukkan bahwa penambahan minuman adpokat fermentasi berpengaruh sangat nyata terhadap kadar kolesterol dan kadar urea dalam darah, tetapi untuk pertambahan berat badan menunjukkan perbedaan yang tidak nyata. Dari hasil penelitian dapat disimpulkan bahwa penggunaan adpokat fermentasi dengan starter bakteri $S$. thermophillus, $L b$ acidophilus dan Lb rhamnosus adalah jenis bakteri yang terbaik untuk menurunkan kadar kolesterol dan dapat menurunkan berat badan pada tikus sampai pada level 7,5 $\mathrm{ml}$ adpokat fermentasi.
\end{abstract}

\footnotetext{
*Jurusan Produksi Ternak
}

Kata Kunci:Kultur starter, S. thermophillus, L. bulgaricus, L. Acidophillus, L. rhamnosus, bakteri asam laktat, berat badan tikus, kolesterol.

\section{ABSTRACT}

THE EFFECTS BEVERAGE OF ADVOCADO FERMENTATION TO RATUS NOVERGICUS WHITE RATS ON CHOLESTEROL, BLOOD UREASE AND WEIGHT EXPERIMENTAL RAT. The objective of this research was to study the effect of using Level advocado fermentation on weight gain, cholesterol and urease on blood of experimental rat. Advocado Fermentation has been made from basic material as advocado fruit, skim milk and sucrose. Three mixed culture starter were used in this research namely: Streptococcus thermophilus, Lactobacillus acidophilus, and Lactobacillus rhamnosus This experiment was arranged in a Completely Randomised desing consisted five treatments with seven replication, were kontrol without added advocado fermentation, R1 added advocado fermentation 2,5ml, R2 added advocado fermentation $5 \mathrm{ml}, \mathrm{R} 3$ added advocado fermentation $7,5 \mathrm{ml}$ and $\mathrm{R} 4$ added advocado fermentation $10 \mathrm{ml}$. Data were analyzed by variance analysis. Significantly difference treatment effects on variables measures were tested using honestly significant diference (HSD). The result showed that treatments have significant difrence $(\mathrm{P}<0.05)$ urease, and 
cholesterol countent on blood, but did not affect significantly $(\mathrm{P}>0.05)$ on body weight rat. The conclution of this research that starter advocado fermentation with starter culture $S$. thermophillus, $L b$ acidophillus and Lb rhamnosus was the best strains for decrease cholesterol countent and level using advocado fermentation with $7,5 \mathrm{ml}$ can decrease body weight of experimental rat.

Keywords: $\quad$ Culture starter, S.thermophillus, L. bulgaricus, L, acidophillus, L. rhamnossus, Lactic acid bacteria, body weight of rats , cholesterol

\section{PENDAHULUAN}

Kolesterol telah menjadi momok di masyarakat kita, karena kadar kolesterol yang tinggi merupakan faktor resiko yang menyebabkan terjadinya penyakit arteroklerosis yaitu suatu penyakit yang berhubungan dengan penyempitan pembuluh darah, terutama yang menuju ke jantung dan otak. Akibatnya akan terjadi penyakit jantung koroner maupun stroke.

Penyakit ini merupakan penyakit pembunuh nomor wahid baik di negara berkembang maupun dinegara yang maju, termasuk Indonesia. Sejak tahun 1992, penyakit ini telah bergeser menjadi urutan pertama penyebab kematian di Indonesia. Akibat masalah ini pemerintah Indonesia menghadapi beban ganda, salah satu pihak masih menghadapi penyakit infeksi namun di pihak lain Indonesia juga menghadapi masalah penyakit degeneratif.

Penyakit lain yang juga dapat menyebabkan kematian adalah Obesitas. Organisasi Kesehatan Dunia menyatakan obesitas sebagai penyebab kematian kedua di dunia. Prevalensi penderita obesitas cendrung meningkat setiap tahunnya. Hal ini disebabkan oleh perubahan pola makan, gaya hidup yang salah, dan faktor genetik. Perubahan pola makan yang tidak baik, misalnya mengkonsumsi makanan yang tinggi kadar lemaknya, garam, dan gulanya tetapi rendah serat dan vitamin serta mengkonsumsi makanan cepat saji (Soegondo, 2006).

Penelitian ini difokuskan untuk meneliti minuman fermentasi yang dibuat dari bahan dasar buah adpokat menggunakan beberapa jenis bakteri asam laktat sebagai starter, bakteri asam laktat yang digunakan antara lain gabungan starter dari $S$. thermophillus dan Lactobacillus bulgaricus, $S$. thermophillus dan L. acidophillus, $S$. thermophillus dan L.casei sub sp. rhamnossus. Bakteri-bakteri ini diketahui merupakan bakteri asam laktat yang sering digunakan dalam pembuatan minuman fermentasi yang menggunakan bahan dasar susu. Seperti diketahui bahwa bakteri asam laktat mempunyai kemampuan dalam menurunkan kadar kolesterol dalam darah.( Chandan dan Shahani, 1993., Jospers dkk.,1984).

Hasil penelitian para ahli di Amerika menyatakan bahwa buah adpokat banyak mengandung asam lemak tidak jenuh dan kaya akan serat. Kandungan dari komponen ini sangat diperlukan untuk memerangi penyakit dislipidemia dan obesitas. Hasil-hasil penelitian menunjukkan bahwa adpokat kaya dengan lemak, tetapi kalori adpokat tidak lebih tinggi dibandingkan dengan buah-buahan lainnya (Apriyadi,2002). Penelitian ini bertujuanuntuk mempelajari sifat biologis pada tikus setelah pemberian adpokat fermentasi dengan melihat 
penurunan berat badan,kadar kolesterol, dan kadar urea dalam darah tikus percobaan, setelah mengkonsumsi adpokat fermentasi pada level yang berbeda.

\section{MATERI DAN METODE PENELITIAN}

\section{Bahan dan Alat}

Bahan-bahan yang digunakan pada penelitian meliputi bahan baku dan bahan kimia untuk analisa. Bahan baku yang digunakan adalah buah adpokat yang sudah matang yang disebut dengan adpokat Mexico dengan ciri-ciri kulit tebal, dan kasar, sedikit ber bintil-bintil dengan berat berkisar 300 gram. Bakteri yang digunakan untuk pembuatan minuman fermentasi adalah adalah Streptococcus thermophilus FNCC 0040 danLactobacillus rhamnosus, L acidophillus diperoleh dari laboratorium Mikrobiologi PAU Pangan Gizi UGM. Bahan lain yang digunakan untuk pembuatan minuman fermentasi ini adalah skim milk, sukrosa dan gelatin. Selain bahan utama dari penelitian juga digunakan bahan-bahan untuk analisa baik kimia maupun mikrobiologis. Untuk uji biologis digunakan yaitu tikus putih jenis wistar betina dengan umur 2 bulan, dengan berat rata-rata 200 gram sebanyak 35 ekor.

Alat-alat penelitian yang digunakan adalah : blender, autoclave, oven listrik, (Heraeus UT 5042 EK), botol timbangan, neraca analitik (Sartorius), inkubator, mikroskop, shaker waterbath (Haake SWB 20 Fisons), waterbath (GFL), sentrifuge (Minifuge T Heraeus), alat-alat gelas, $\mathrm{pH}$ meter (Toa HM 205), magnetic stirrer, vortex, refrigerator, dan alatalat gelas lainnya. Peralatan untuk analisa biologis meliputi kandang tikus dan perlengkapannya serta alatalat lain yang dibutuhkan untuk penentuan kadar kolesterol darah.

\section{Pembuatan Minuman Fermentasi}

\section{a) Pembuatan jus adpokat.}

Pembuatan jus adpokat diawali dengan membersihkan kulit buah adpokat dengan pencucian dan penirisan buah. Buah yang telah bersih dihilangkan kulit buahnya. Daging buah yang telah dihilangkan kulitnya selanjutnya dikeluarkan dari biji. Setelah itu daging buah diblender dengan menambahkan air dengan perbandingan $1: 3$. Untuk setiap berat 100 gram daging buah ditambah air sebanyak $300 \mathrm{ml}$. Adpokat yang sudah diblender siap untuk digunakan.

b) Pembuatan Starter dari bakteri asam laktat.

Pembuataan starter bakteri asam laktat yang akan digunakan mengaju pada metoda Nsofos et al. (1992) yakni skim milk $8 \%$ ditambahkan sukrosa $1 \%$ disterilkan pada suhu $115^{\circ} \mathrm{C}$ selama 10 menit, kemudian dinginkan sampai temperatur $45^{\circ} \mathrm{C}$. Kemudian inokulasi masing masing dengan bakteri asam laktat yang digunakan (S. Thermophillus, Lactobacillus rhamnosus, danLb acidophillus). Inkubasi dilakukan pada suhu $36^{\circ} \mathrm{C}$ selama 18 jam.

c) Pembuatan Minuman fermentasi adpokat (yoghurt adpokat).

Proses pembuatan minuman fermentasi dari adpokat mengacu pada proses pembuatan yoghurt pada santan kelapa yang dimodifikasi yang telah dilakukan Yelnetty (2000). Pada pembuatan minuman fermentasi buah 
adpokat terlebih dahulu siapkan air matang yang dingin sebanyak 1 liter kemudian tambahkan skim $8 \%$,sukrosa $6 \%$, homogenisasi menggunakan blender selama 1menit, kemudian pasteurisasi pada temperatur $85^{\circ} \mathrm{C}$ selama 15 menit, sebelum pengangkatan masukkan jus adpokat yang telah disiapkan. Lakukan pendinginan sampai temperatur campuran bahan digin $\left(40^{\circ} \mathrm{C}\right)$. Lakukan inokulasi dengan starter yang telah disiapkan terlebih dahulu sebanyak $5 \%$ dengan perbandingan antara bakteri Streptococcus dan Lactobacillus 1:1. Inkubasi dalam inkubator pada temperatur $43^{\circ} \mathrm{C}$ selama 6 jam atau sampai terbentuknya puding pada bahan. Simpan dalam lemari pendingin sampai analisa dilakukan.

\section{Pemeliharaan Hewan Coba.}

Pemeliharaan tikus dilakukan di Laboratorium Unit Pengembangan Hewan Percobaan (UPHP) Universitas Gadjah Mada sebanyak 35 ekor tikus putih jenis wistar umur 3 bulan, dengan berat rata-rata 200 gram. Tikus dimasukkan dalam kandang individual secara tertutup dengan kondisi kandang terkontrol, ventilasi udara dalam kandang cukup tersedia. Pakan adaptasi diberikan selama 14 hari dengan menggunakan pakan standar, kemudian tikus dikelompokkan menjadi 5 kelompok yakni kelompok I, kelompok II, kelompok III, kelompok IV dan Kelompok V. Masing-masing kelompok diberi pakan kolesterol tinggi selama 10 hari untuk menaikkan kadar kolesterol dalam darah, setelah itu tikus dipuasakan dan diambil darahnya untuk mengukur kadar kolesterol (kolesterol total, LDL HDL dan Trigliserida) dan juga diukur berat badan dari pada tikus percobaan. Kemudian, sesuai dengan kolompoknya, tikus diberikan perlakuan. Tikus kelompok I diberi pakan standar tapi hanya diberi aquades, tanpa pemberian adpokat fermentasi setiap hari, kelompok II merupakan tikus yang diberi pakan standar dan minuman fermentasi adpokat setiap hari 2,5 gram $/ \mathrm{kg}$ bb (pemberian pagi), kelompok III merupakan tikus yang diberi pakan standar dan minuman adpokat sebanyak 5 gram $/ \mathrm{Kg}$ bb setiap hari, kelompok IV merupakan kelompok tikus yang diberi pakan standar dan minuman fermentasi adpokat sebanyak 7,5 gram/Kg bb. Kelompok $\mathrm{V}$ adalah kelompok tikus yang diberi pakan standar dan adpokat fermentasi sebanyak 10 gram/Kg bb.

Pemberian pakan dan air minum untuk tikus diberikan secara adlibitum. Air aquadest steril juga diberikan $2 \mathrm{x}$ setiap hari sebanyak 6 cc setiap pemberiannya dan diberikan pada kelompok kontrol. Baik minuman fermentasi maupun aquadest steril diberikan secara paksa (forced feeding). Pengukuran berat badan dilakukan setiap 2 hari sekali.

Perlakuan berlangsung selama 21 hari, setelah itu tikus dipuasakan 1 hari dan semua tikus pada setiap perlakuan diambil darahnya lewat mata (retrobital plexus) dengan menggunakan tabung mikro hematokrit untuk analisis kadar kolesterol total, urea, dan berat badan hewan percobaan(Astuti,1998). 


\section{Pengambilan Specimen}

Untuk memperoleh serum darah disentrifus selama 10 menit dengan kecepatan $3500 \mathrm{rpm}$ selama 15 menit untuk dianalisa dengan menggunakan spektrofotometer.Pada akhir penelitian semua tikus percobaan dibunuh, kemudian dilakukan bedah mayat untuk mengetahui perubahanperubahan organ tubuh yang mungkin ada. Sampel jaringan hati, diambil dan difiksasi dalam formalin $10 \%$ selanjutnya diproses untuk pemeriksaan histopatologik dengan metode seperti yang dipakai di BPPH(Balai Penyidikan Penyakit Hewan). Total kolesterol dianalisa menurut metode Richmond, 1973, Kolesterol LDL menurut metode Wieland dan Seidel, 1983, HDL menggunakan metode Eckel et al., (1977) analisa Trigliserida menggunakan metode Mc Gowan (1983).

ANALISIS DATA.

Tabel 1. Pertambahan Berat Badan Tikus Percobaan Setelah Pemberian Minuman Fermentasi Adpokat.

\begin{tabular}{|c|c|c|c|c|c|c|c|c|c|}
\hline \multirow{2}{*}{$\begin{array}{l}\text { Perla- } \\
\text { kuan }\end{array}$} & \multicolumn{7}{|c|}{ Jumlah Tikus/ Pertambahan berat badan (gram) } & \multirow[t]{2}{*}{ Total } & \multirow{2}{*}{$\begin{array}{l}\text { Rata- } \\
\text { rata }\end{array}$} \\
\hline & 1 & 2 & 3 & 4 & 5 & 6 & 7 & & \\
\hline R0 & 307,5 & 261,6 & 264,1 & 309,3 & 304,2 & 276,5 & 308,7 & 2031,9 & $290,27^{\mathrm{a}}$ \\
\hline R1 & 297,0 & 273,0 & 309,8 & 308,8 & 292,8 & 281,6 & 306,2 & 2069,6 & $290,06^{\mathrm{a}}$ \\
\hline R2 & 278,2 & 306,0 & 279,5 & 254,4 & 300,1 & 233,7 & 304,5 & 1956,4 & $279,48^{\mathrm{a}}$ \\
\hline R3 & 284,3 & 283,6 & 299,8 & 323,2 & 294,3 & 227,2 & 245,6 & 1958,0 & $279,71^{\mathrm{a}}$ \\
\hline R4 & 357,4 & 326,0 & 273,8 & 265,6 & 264,3 & 303,4 & 308,8 & 2099,3 & $285.61^{\mathrm{a}}$ \\
\hline
\end{tabular}

Ket: Superscrip yang sama menyatakan tidak berbedanyata*

Dari hasil analisa diketahui bahwa pertambahan berat badan pada tikus percobaan setelah pemberian adpokat fermentasi pada level yang berbedabeda berkisar antara antara 279,48 gram sampai290,06 gram. Rataan pertambahan berat badan yang
Percobaan dilakukan dengan menggunakan Rancangan Acak Lengkap dengan perlakuan adalahjumlah pemberian minuman adpokat fermentasi yang diberikan pada tikus percobaan. Data yang diperoleh dianalisa dengan analisa varian dan kalau didapatkan perbedaan dilanjutkan dengan uji HSD. (Steel and Torrie, 1990).

\section{HASIL DAN PEMBAHASAN}

\section{ANALISIS BIOLOGIS}

\section{Berat Badan Tikus Percobaan}

Data perubahan berat badan pada Tikus percobaan selama perlakuan dapat dilihat pada Tabel 1. Sebelum diberi perlakuan tikus terlebih dahulu diadaptasi dengan pakan standar selama 1 minggu dan setelah itu diberi pakan kolesterol tinggi. Perubahan berat badan setelah pemberian adpokat fermentasi dapat dilihat pada Tabel 1 . 
tikus yang diberi konsumsi adpokat fermentasi dengan dosis 10 gram perhari, dan kemudian diikuti oleh kelompok tikus yang tidak diberi minuman fermentasi adpokat dan sebagai penggantinya diberikan aquadest dan kelompok tikus ini adalah kelompok kontrol pada percobaan yang dilakukan. Pertambahan berat badan pada kelompok terakhir kemungkinan disebabkan bahwa pemberian minuman adpokat yang berlebihan menghasilkan pertambahan berat badan.

$\begin{array}{ccr}\text { Hasil } & \text { Analisa } & \text { Ragam } \\ \text { menunjukkan } & \text { bahwa } & \text { pengaruh }\end{array}$
perlakuan pada setiap kelompok hewan coba menghasilkan pengaruh berbeda tidak nyata $(\mathrm{P}>0.05)$ terhadap berat badan tikus percobaan. Dengan pengertian bahwa setiap perlakuan yang diberikan pada hewan percobaan tidak menyebabkan terjadinya perobahan yang signifikan baik antara kelompok yang tidak diberi (kontrol) maupun kelompok yang diberi minuman fermentasi adpokat. Hal ini berarti bahwa pemberian adpokat fermentasi sampai dosis 10 gram per ekor perhari tidak mempengaruhi pertambahan kenaikan berat badan pada tikus percobaan dan dosis yang digunakan secara statistik tidak berpengaruh terhadap berobahan berat badan yang dihasilkan.

\section{Kadar Kolesterol Total}

Data perubahan kadar kolesterol pada hewan percobaan selama perlakuan dapat dilihat pada Tabel 2 . Sebelum diberi perlakuan tikus terlebih dahulu diadaptasi dengan pakan standar selama 1 minggu dan setelah itu diberi pakan kolesterol tinggi,dan kemudian diberi minuman adpokat fermentasi.

Hasil penelitian menunjukkan kadar kolesterol pada kelompok tikus yang diberi pakan standar tanpa pemberian minuman fermentasi dibandingkan dengan kelompok tikus yang diberi minuman fermentasi dari adpokat. Rataan kadar kolesterol tikus percobaan setelah akhir perlakuan berkisar antara $63,54 \mathrm{mg} / \mathrm{dl}$ sampai $71,40 \mathrm{mg} / \mathrm{dl}$. Kadar kolesterol total tertinggi terdapat pada kelompok tikus kontrol yang tidak diberi minuman fermentasi adpokat sebesar 71,40 mg/dl, sedangkan kadar kolesterol terendah diperoleh dari kelompok tikus yang diberi minuman fermentasi adpokat dengan level 7,5 ml/ekor/hari yakni kelompok hewan percobaan R3 dan kadar kolesterol rata-rata yang dihasilkan yakni63,54 mg/dl.

\section{KESIMPULAN}

Sistem pertanian agroforestri dengan pohon buah-buahan, pohon pengikat nitrogen, kayu-kayuan merupakan suatu system yang menguntungkan baik secara ekologi, ekonomi, dan sosial. Keuntungan ekologis dari sistem agroforestri berupa terpeliharanya fungsi tata air, kesuburan tanah, keanekaragaman hayati, dan sebagai cadangan karbon. Keuntungan secara ekonomi dan sosial berupa perolehan air dan udara yang bersih dan peningkatan kesejahteraan masyarakat sekitarnya.

\section{DAFTAR PUSTAKA}

Coates, B. J. and Bishop, K. D. 1997. Panduan Lapangan BurungBurung Di Kawasan Wallacea, 
Sulawesi, Maluku, dan Nusa Tenggara. BirdLife International-Indonesia Programme \& Dove Publ.

Irwan, Z. D. 1992. Prinsip-Prinsip Ekologi dan Organisasi, Ekosistem, Komunitas, dan Lingkungan. Penerbit Bumi Aksara. Jakarta.

Odum, E.H. 1993. Dasar-Dasar Ekologi. Penerbit Gadjah Mada Press, Yokyakarta.

Reosodarmo, S. 1986. Pengantar Ekologi. Penerbit Remadja Rosda Karya. Bandung.

Soemarwoto, O. 1983. Ekologi Lingkungan Hidup dan Pembangunan. Penerbit Djambatan. Jakarta.

Umamit, K. 2007. Keragaman Jenis Burung di Kawasan Cagar Alam Gunung Ambang. Tesis S1. UDK Kotamobagu.

White, C.M.N and M. D. Bruce. 1986. The Birds of Wallacea (Sulawesi, The Molluccas, and Lesser Sunda Island). British Ornithologists Union. London. 